\title{
ANALISIS EFISIENSI FAKTOR PRODUKSI USAHATANI TEMBAKAU RAKYAT (Studi Empiris : Desa Munggangsari, Kecamatan Kaliangkrik, Kabupaten Magelang)
}

\author{
Hendrik Widiyanto \\ Email : gamboelnesia@gmail.com \\ Edy Yusuf Agung Gunanto \\ Email: edy.yusuf.ag@gmail.com \\ Nugroho SBM \\ Departemen IESP Fakultas Ekonomika dan Bisnis Universitas Diponegoro \\ Email:nugroho_sbm@yahoo.co.id_nugroho.sbm@gmail.com
}

\begin{abstract}
Abstrak
Kabupaten Magelang merupakan salah satu penghasil tembakau terbesar di Jawa Tengah, salah satu yang menghasilkan produksi ada di Desa Munggangsari, Kecamatan Kaliangkrik, Kabupaten Magelang. Tujuaan penelitian ini untuk mengetahui faktor apa saja yang mempengaruhi produksi tembakau di Desa Munggangsari. Data penelitian ini adalah data primer dan data sekunder. Data primer diperoleh dari interview dengan kuesioner, data sekunder diperoleh dari buku dan literature dari berbagai sumber. Pengambilan sampel responden dalam penelitian ini adalah petani tembakau di Desa Munggangsari, Metode analisis dalam penelitian ini adalah analisis regresi (software e-views 7) dan uji efisiensi (software $D E A P$ ). Hasil penelitian menunjukkan terdapat empat variabel yang berpengaruh signifikan terhadap produksi tembakau yaitu luas lahan, bibit, pupuk organik, fungisida. Sedangkan variabel tenaga kerja, pupuk SP36, dan pupuk ZA, tidak berpengaruh siginifikan terhadap produksi tembakau di desa Munggangsari. Nilai efisiensi teknis petani tembakau adalah 0.651 maka perlu dilakukan penambahan jumlah faktor produksi sehingga nilai efisiensi teknisnya 1.
\end{abstract}

Kata Kunci : Efisiensi, Fungsi Produksi Cobb-Douglas, Tembakau, DEA.

\begin{abstract}
Magelang regency is one of the largest tobacco producers in Central Java, one of which produces production in Munggangsari Village, Kaliangkrik Subdistrict, Magelang Regency. The purpose of this study to determine what factors affect the production of tobacco in the village of Munggangsari. The data of this research are primary data and secondary data. Primary data were obtained from interviews with questionnaires, secondary data obtained from books and literature from various sources. Sampling of respondents in this study is tobacco farmers in Munggangsari Village, the method of analysis in this study is regression analysis (software e-views 7) and efficiency test (software DEAP). The results showed there are four variables that significantly affect tobacco production that is the area of land, seeds, organic fertilizer, and fungicide. While the variable labor, SP36 fertilizer, and ZA fertilizer, no significant effect on tobacco production in the village Munggangsari. The technical efficiency value of tobacco farmers is 0.651 it is necessary to add the number of factors of production so that the value of technical efficiency 1.
\end{abstract}

Keywords: Efficiency, Cobb-Douglas Production Function, Tobacco, DEA. 


\section{PENDAHULUAN}

Indonesia merupakan negara agraris dimana sektor pertanian merupakan sektor utama, baik sebagai mata pencaharian maupun penopang pembangunan dalam perekonomian. Sektor pertanian menjadi penyumbang terbesar setelah pengolahan industri terhadap Produksi Domestik Bruto (PDB), terhadap penyerapan tenaga kerja, dan juga terhadap ekspor. Hasil-hasil pertanian di Indonesia mampu dijadikan komoditas unggulan dalam persaingan global. Pembangunan pertanian yang sudah cukup berhasil dicapai oleh Indonesia pada tahun 1970-an sampai tahun 1980-an, ditandai dengan meningkatnya pertumbuhan PDB (Produk Domestik Bruto) sektor pertanian sebesar $3,2 \%$ per tahunnya. Terjadinya krisis ekonomi yang melanda Indonesia pada pertengahan 1997 menunjukkan bahwa sektor pertanian dapat bertahan dari sektor yang dibangga-banggakan pada tahun tersebut yaitu sektor industri. Bahkan sektorpertanian mengalami pertumbuhan sebesar $0,22 \%$.

Data dari BPS tahun 2016 luas lahan dan jumlah produksi tembakau rakyat di Jawa Tengah mengalami fluktusai. Pada tahun 2011 produksi tembakau di Provinsi Jawa Tengah sebesar 34.290,46 ton (sebesar 21.8\%) dengan luas lahan sebesar 44.969,17 ha, dan pada tahun 2015 produksi tembakau kembali mengalami peningkatan jumlah produksi sebesar $35.048,00$ ton (sebesar 22,3\%). Hal ini dipengaruhi oleh cuaca yang mendukung dan bertambahnya luasan lahan tembakau yang cukup signifikan dari tahun sebelumnya. terdapat daerah seperti Kab. Magelang, Kab. Kendal, Kab. Wonosobo, Kab. Rembang juga memiliki luasan lahan dan tingkat produksi yang cukup tinggi. Salah satu daerah dengan luas lahan yang cukup tinggi adalah Kab. Magelang dengan luas lahan $6.613,00$ ha atau $13,89 \%$ dari total luas lahan dengan jumlah produksi sebesar 4.289,00 ton atau sekitar $12,26 \%$ dari total produksi tembakau di provinsi Jawa Tengah.
Tabel 1. Luas Lahan, Jumlah Produksi, Produktivitas Tembakau Rakyat Kabupaten Magelang 2011-2015

\begin{tabular}{lllll}
\hline No & Tahun & $\begin{array}{c}\text { Luas Lahan } \\
\text { (ha) }\end{array}$ & $\begin{array}{c}\text { Produksi } \\
\text { (ton) }\end{array}$ & $\begin{array}{c}\text { Produktivitas } \\
\text { (ton/ha) }\end{array}$ \\
\hline 1 & 2011 & 6010 & 3781 & 0.63 \\
2 & 2012 & 7108 & 3584 & 0.50 \\
3 & 2013 & 4206 & 2309 & 0.55 \\
4 & 2014 & 5011 & 3249 & 0.65 \\
5 & 2015 & 6613 & 4298 & 0.65 \\
\hline \multicolumn{5}{l}{ Sumber: Dinas Pertanian, Perkebunan dan Kehutanan Kabupaten Magelang }
\end{tabular}

Secara umum luas lahan dan jumlah produksi tembakau rakyat dari tahun 2011 sampai tahun 2015 meningkat, disertai dengan peningkatan produktivitas tembakau yaitu 0.63 pada tahun 2011 dan 0.65 pada tahun 2015. Namun, produktivitas tembakau rakyat di Kabupaten Magelang masih dikategorikan rendah karena belum mencapai target kinerja urusan pertanian Rencana Pembangunan Jangka Menengah Daerah (RPJMD) Kabupaten Magelang Tahun 2014-2019 yaitu sebesar 0,95 (BAPPEDA Kabupaten Magelang, 2014). Selain itu, produktivitas tembakau rakyat di Kabupaten Magelang masih rendah dibandingkan dengan daerah penghasil tembakau rakyat lainnya di Jawa Tengah seperti di Kabupaten Kendal yang produktivitasnya mencapai 1,16 , Kabupaten Pati dengan produktivitas 1,56. Produktivitas yang masih rendah ini dapat terjadi karena penggunaan faktor produksi yang kurang optimal. Kecamatan Kaliangkrik yang memiliki tingkat produksi tembakau tertinggi dibandingkan dengan kecamatan lainnya di Kabupaten Magelang. Desa Munggangsari memiliki luas tanam terbesar. Namun hasil produksi tembakau didesa Munggangsari lebih rendah dengan desa lain.

Penelitian ini bertujuan untuk menganalisis pengaruh penggunaan faktorfaktor produksi seperti lahan, bibit, pupuk kandang, pupuk ZA, pupuk SP36, pestisida, dan tenaga kerja terhadap jumlah produksi tembakau di Kabupaten Magelang serta menganalisis tingkat efisiensi teknis, efisiensi harga, dan 
efisiensi ekonomis usahatani tembakau di Kabupaten Magelang.

\section{KERANGKA PEMIKIRAN TEORITIS DAN PERUMUSAN HIPOTESIS}

Dalam usahatani tembakau membutuhkan beberapa faktor - faktor produksi antara lain luas lahan, bibit, pupuk kandang, pupuk ZA, pupuk SP36, pestisida, dan tenaga kerja sebagai input variabel. Kombinasi faktor - faktor produksi tersebut menghasilkan sejumlah produksi tertentu yang dapat dianalisis tingkat efisiensi teknis, efisien harga, maupun efisiensi ekonomis.

Hipotesis :

1. Diduga variabel luas lahan berpengaruh signifikan terhadap produksi tembakau.

2. Diduga variabel bibit berpengaruh signifikan terhadap produksi tembakau.

3. Didudga variabel pupuk organik berpengaruh signifikan terhadap produksi tembakau.

4. Diduga variabel pupuk ZA berpengaruh signifikan terhadap produksi tembakau.

5. Diduga variabel pupuk SP36 berpengaruh signifikan terhadap produksi tembakau.

6. Diduga variabel fungisida berpengaruh signifikan terhadap produksi tembakau.

7. Diduga variabel tenaga kerja berpengaruh signifikan terhadap produksi tembakau.

\section{Penelitian Terdahulu}

1. Analisis Efisiensi Produksi Kopi Robusta Di Kabupaten Temanggung. (Tri Risandewi). Metodologi yang digunakan adalah DEA dan Regresi statistik parametrik. Tujuan penelitian adalah mengetahui tingkat efisiensi produksi usaha perkebunan kopi dan menganalisis faktor produksi yang mempengaruhi tingkat produksi kopi rakyat di Kecamatan Candiroto.
2. Analisis Efisiensi Produksi Usahatani Tembakau Kabupaten Temanggung. (Huda Hardanis). Metodologi yang digunakan adalah regresi dari fungsi produksi Cobb-Douglas yang perhitungannya menggunakan persamaan regresi linier berganda. Tujuan penelitian ini adalah Menganalisis tingkat efisiensi teknis, efisiensi harga, efisiensi ekonomis usahatani di Kabupaten Temanggung.

3. Analisis Efisiensi Teknis Usahatani Tembakau (Suatu Kajian Dengan Menggunakan Fungsi Produksi Frontier Stokhastik). (Elys Fauziyah). Metodologi yang digunakan adalah Fungsi Produksi Frontier Stochastic. Tujuan penelitian ini adalah Menganalisis faktor faktor yang mempengaruhi produksi dan menganalisis tingkat efisiensi teknis yang dicapai oleh setiap petani.

4. Identifikasi Faktor-Faktor Utama Yang Berpengaruh Pada Efisiensi Usahatani Bawang Merah Di Desa Sisalam, Kecamatan Wanasari, Kabupaten Brebes. (Gunistiyo). Metodologi yang digunakan adalah regresi dari fungsi produksi Cobb-Douglas yang perhitungannya menggunakan persamaan regresi linier berganda. Tujuan penelitian ini adalah Untuk mengetahui pengaruhfaktor produksi yang terdiri atas lahan, bibit, tenaga kerja, dan pupuk terhadapproduksi bawang merah.

\section{METODE PENELITIAN}

\section{Variabel Penelitian}

1. Jumlah Produksi (Y) adalah jumlah daun tembakau basah yang dihasilkan oleh petani dalam satu kali masa panen $(\mathrm{kg})$.

2. Bibit (BT) adalah Jumlah pemakaian bibit tembakau dalam proses produksi 
dalam satu kali masa tanam. Dalam satuan batang (bt).

3. Pupuk Organik atau pupuk kandang (PKG) jumlah pemakaian pupuk per hektar yang digunakan dalam satuan kilogram $(\mathrm{kg})$.

4. Jumlah penggunaan pupuk anorganik berupa pupuk ZA dalam satu kali masa tanam dengan satuan kilogram $(\mathrm{kg})$.

5. Jumlah penggunaan pupuk anorganik berupa pupuk SP36 dalam satu kali masa tanam dengan satuan kilogram $(\mathrm{kg})$.

6. Fungisida atau pestisida (FSD) adalah jumlah pemakaian fungisida atau perstidida per hektar dalam satuan liter (1 lt).

7. Tenaga kerja (TK) adalah jumlah tenaga kerja yang dipakai dalam usahatani tembakau dalam satu kali masa tanam mulai dari mengolah tanah, penanaman, pemeliharaan, sampai panen baik dari dalam keluarga maupun dari luar keluarga. Didasarkan satuan Hari Orang Kerja (HOK) dengan anggapan satu hari kerja adalah tujuh jam. Tenaga kerja yang digunakan tidak dibedakan atas jenis kelamin.

\section{Populasi dan Sampel}

Dalam penelitian ini menggunakan data populasi petani yang menanam tembakau di lahan miliknya sendiri maupun lahan sewa. Adapun penelitian akan dilakukan di Desa Munggangsari, Kecamatan kaliangkrik, Kabupaten Magelang. Jumlah populasi petani dari lokasi penelitian ini adalah 620 orang yang terbagi atas 3 Dukuh, yaitu Dukuh Kuwayuhan, dengan jumlah petani 205 Orang, Dukuh Derepan, dengan jumlah petani 105 Orang, Dukuh Munggangsari, dengan jumlah petani 310 Orang. Untuk menentukan jumlah sampel dari suatu populasi salah satunya adalah menggunakan rumus slovin (dikutip oleh Silaen, 2003).

$$
\mathrm{n}=\frac{\mathrm{N}}{1+\mathrm{N}(e)^{2}}
$$

$\mathrm{n}$ : Jumlah Sampel

$\mathrm{N}$ : Populasi

E : Nilai Kritis (batas ketelitian) yang diinginkan (persen kelonggaran ketidaktelitian karena kesalahan pengambilan sampel populasi). Jika nilai kritis yang dipakai adalah 10\%, maka dapat diketahui jumlah sampel yang digunakan sebagai berikut :

$\mathrm{n}=\frac{620}{1+620(0.01)}=86$ responden

Rumus tersebut akan digunakan untuk menentukan jumlah sampel di tiga dukuh yang ada di Desa Munggangsari pada penelitian ini.

$\begin{array}{ccccc} & & & 205 \\ 1 & \text { Kulwayuhan } & 205 & 86=29.11 & \\ 2 & \text { Derepan } & 105 & \frac{105}{620} \times 86=14.89 & \\ 3 & \text { Munggangsan } & 310 & \frac{310}{620} \times 86=41.98 & 42 \\ & & & & \\ & & & \\ & \text { Jumlah } & 620 & & \end{array}$

Pengambilan sampel di Desa Munggangsari karena desa tersebut memiliki jumlah petani paling banyak di kecamatan Kaliangkrik.pengambilan sampel dilakukan di Dukuh Kuwayuhan sebanyak 29 responden, Dukuh Derepan 15 responden, dan Dukuh Munggangsari sebanyak 42 responden. Total terdapat 86 responden yang diambil sebagai sampel dalam penelitian ini dengan karakteristik petani adalah petani pemilik penggarap, pengambilan sampel dilakukan secara acak sederhana (simple Random Sampling).

\section{Metode Analisis}

Metode analisis yang digunakan dalam penelitian ini adalah analisis regresi guna menentukan faktor-faktor produksi yang efisien. Model regresi yang 
digunakan dalam penelitian ini adalah sebagai berikut :

$$
\begin{aligned}
\operatorname{Ln} Y=\operatorname{Ln} A+ & \beta_{1} \operatorname{Ln} L H N+\beta_{2} \operatorname{Ln} B+\beta_{3} \operatorname{Ln} P K G \\
& +\beta_{4} \operatorname{Ln} P Z A+\beta_{5} \operatorname{Ln} P S P \\
& +\beta_{6} \operatorname{Ln} F S D+\beta_{7} \operatorname{LnTK}+e
\end{aligned}
$$

Keterangan :

Y : Jumlah Produksi Tembakau

PKG : Pupuk organik (kg)

A : Konstanta

PZA : Pupuk ZA (kg)

LHN : Luas lahan $\left(\mathrm{m}^{2}\right)$

PSP : Pupuk SP36 $(\mathrm{kg})$

BT : Bibit Tembakau (bt)

FSD : Fungisida / pestisida

T :Tenaga Kerja (HOK)

$\beta \quad$ : Koefisien

$e \quad$ : Error Term (Kesalahan Pengganggu)

Adanya perbedaan dalam satuan dan besaran variabel bebas maka persamaan regresi harus dibuat dengan model logaritma natural. Alasan pemilihan model logaritma natural (Imam Ghozali, 2005) adalah 1. Menghindari ada heterokesdatisitas, 2. Mengetahui koefisien yang menunjukkan elastisitas, 3. Mendekatkan skala data.

\section{HASIL PENELITIAN DAN PEMBAHASAN}

\section{Karakteristik Responden}

Usia responden petani tembakau di Desa Munggangsari, kecamatan Kaliangkrik, Kabupaten Magelang berkisar antara 34-65 tahun keatas. Usia paling banyak adalah usia 46-51 tahun, dimana pada usia tersebut petani telah banyak pengalaman dalam bertani tembakau, sehingga telah ahli dalam pengelolaan usahatani tembakau, usia responden dapat dilihat pada Tabel 2 .
Tabel 2. Karakteristik Responden Menurut Usia

\begin{tabular}{ccc}
\hline Usia & $\begin{array}{c}\text { Jumlah } \\
\text { Responden }\end{array}$ & Frekuensi \\
\hline $34-39$ & 10 & $11,62 \%$ \\
$40-45$ & 19 & $22,09 \%$ \\
$46-51$ & 25 & $29,06 \%$ \\
$52-57$ & 22 & $25,58 \%$ \\
$58-64$ & 6 & $6,97 \%$ \\
65 atau lebih & 4 & $4,65 \%$ \\
\hline Total & $\mathbf{8 6}$ & $\mathbf{1 0 0 \%}$ \\
\hline Sumper; Data Primer 2017, diolah
\end{tabular}

Jumlah tanggungan keluarga yang memiliki frekuensi terbanyak terdapat pada interval 1 hingga 3 orang dengan tingkat distribusi sebesar 72,09\% dari keseluruhan responden. Selanjutnya jumlah tanggungan keluarga dengan frekuensi terbanyak kedua, ada pada interval 4 hingga 6 orang dengan jumlah 24 orang dan presentase distribusi 24,90 $\%$. Jumlah tanggungan anggota keluarga responden dapat dilihat pada tabel berikut.

Tabel 3. Jumlah Tanggungan Keluarga

\begin{tabular}{ccc}
\hline $\begin{array}{c}\text { Jumlah Tanggungan } \\
\text { Keluarga }\end{array}$ & Responden & Frekuensi \\
\hline $1-3$ & 62 & $72,09 \%$ \\
$4-6$ & 24 & $27,90 \%$ \\
\hline Total & $\mathbf{8 6}$ & $\mathbf{1 0 0 \%}$ \\
\hline \multicolumn{2}{c}{ Sumber: Data Primer 2017, diolah } \\
\end{tabular}

Pekerjaan utama merupakan pekerjaan dengan tingkat prioritas pertama yang diandalkan responden untuk mendapatkan penghasilan. Selain itu pekerjaan utama biasanya menunjukkan bidang keahlian utama dari para responden. Hampir sebagian besar responden di lokasi penelitian berprofesi sebagai petani dengan jumlah 76 orang atau 88,37 \% dari keseluruhan responden. Sedangkan jenis pekerjaan utama responden yang lain adalah sebagai pegawai negeri sipil (PNS), yang 
berjumlah 10 orang dengan presentase hanya $11,62 \%$ dari 86 responden.

\section{Tabel 4. Pekerjaan Utama Responden}

\begin{tabular}{ccc}
\hline Pekerjaan Utama & Responden & Frekuensi \\
\hline Petani & 76 & $88,37 \%$ \\
PNS & 10 & $11,62 \%$ \\
\hline Total & $\mathbf{8 6}$ & $\mathbf{1 0 0 \%}$ \\
\hline \multicolumn{2}{c}{ Sumber:Data Primer 2017, diolah }
\end{tabular}

Salah satu bagian yang tidak kalah penting dalam keberhasilan suatu usahatani adalah lamanya pengalaman seseorang dalam berkecimpung pada sektor pertanian. Responden yang memiliki pengalaman usahatani tembakau dari 15 sampai 18 tahun, berjumlah 12 orang dengan presentase distribusi 13,95 $\%$ dari 86 responden. Jumlah responden pada rentan usia 19 sampai 22 tahun mempunyai frekuensi sebesar 18 orang dengan presentase tingkat distribusi sebesar 20,93\%, sedangkan pengalaman usahatani tembakau dengan jumlah responden terbanyak berada pada rentan usia 23 sampai 26 tahun dengan jumlah 29 orang dan presentase distribusi sebesar $33,72 \%$. Responden dengan jumlah terbanyak ke dua berada pada rentan usia 27 hingga 30 tahun dengan jumlah responden sebanyak 22 orang, dengan presentase distribusi 25,58 \%. Dan jumlah responden dengan rentan pengalaman kerja dibidang usahatani tembakau yang paling sedikit berada pada rentan usia 31 tahun atau lebih, sebesar 5 orang responden, dengan presentase distribusi $5,81 \%$. Pengalaman usahatani terhadap responden di Desa Munggangsari, Kecamatan Kaliangkrik, Kabupaten Magelang dapat dilihat melalui tabel 5 berikut :
Tabel 5. Karakteristik Responden Menurut Pengalaman Kerja

\begin{tabular}{ccc}
\hline $\begin{array}{c}\text { Pengalaman Kerja } \\
\text { (tahun) }\end{array}$ & Responden & Frekuensi \\
\hline $15-18$ & 12 & $13,95 \%$ \\
$19-22$ & 18 & $20,93 \%$ \\
$23-26$ & 29 & $33,72 \%$ \\
$27-30$ & 22 & $25,58 \%$ \\
31 atau lebih & 5 & $5,81 \%$ \\
\hline Total & $\mathbf{8 6}$ & $\mathbf{1 0 0 \%}$ \\
\hline Sumber; Data Primer 2017, diolah &
\end{tabular}

Kondisi tingkat pendidikan seseorang responden dapat menentukan keterbukaan seseorang dalam menerima informasi, paradigma, dan penguasaan seseorang dalam menggunakan alat-alat maupun teknologi. Sebagian besar responden yang ditemui oleh peneliti hanya mengeyam pendidikan sekolah dasar dengan frekuensi 49 Orang. Responden dengan tingkat pendidikan sekolah dasar tersebut terdistribusi sebesar $53,48 \%$ dari 86 responden. Sedangkan responden dengan tingkat pendidikan perguruan tinggi menempati peringkat paling akhir dengan jumlah hanya 2 orang serta terdistribusi sebesar 2,32\%. Responden yang tidak lulus atau tidak bersekolah berada di peringkat ke dua terbesar setelah Sekolah Dasar. Tercatat responden yang tidak lulus atau tidak bersekolah tersebut, berjumlah 20 orang dengan presentase frekuensi 23,25 \%. Pendidikan di tingkat Sekolah Menengah Pertama (SMP) berjumlah 10 orang responden dengan presentase $11,62 \%$. Sedangkan responden yang berhasil menyelesaikan tingkat pendidikan Sekolah Menengah Atas (SMA) berjumlah 5 orang dengan presentase frekuensi 5,81\% dari 86 responden. 
Tabel 6. Tingkat Pendidikan Responden

\begin{tabular}{ccc}
\hline Pendidikan & Responden & Frekuensi \\
\hline $\begin{array}{c}\text { Tidak Lulus atau } \\
\text { Tidak Sekolah }\end{array}$ & 20 & $23,25 \%$ \\
SD & 49 & $53,48 \%$ \\
SMP & 10 & $11,62 \%$ \\
SMA & 5 & $5,81 \%$ \\
Perguruan Tinggi & 2 & $2,32 \%$ \\
\hline Total & $\mathbf{8 6}$ & $\mathbf{1 0 0 \%}$ \\
\hline \multicolumn{2}{c}{ Sumber:-Data Primer 2017, diolah }
\end{tabular}

\section{Deskripsi Variabel}

Lahan merupakan salah satu variabel penting dalam pertanian, tanpa adanya lahan hasil sektor pertanian mungkin bisa terhambat karena tidak ada media tanam yang dapat di tanami komoditas tertentu. Penggunaan luas lahan untuk tiap petani tembakau di lokasi penelitian cukup beragam, yaitu antara $3000 \mathrm{~m}^{2}$ hingga $8000 \mathrm{~m}^{2}$. Secara keseluruhan lahan yang digunakan oleh petani adalah lahan dengan status kepemilikan sendiri.

Pemilihan bibit merupakan salah satu aspek penting bagi para petani. Hal tersebut dikarenakan varietas bibit dapat mempengaruhi hasil produksi suatu komoditas. Ketika para petani memilih untuk menanam bibit yang unggul, hal tersebut akan menguntungkan petani karena hasil yang didapatkan akan jauh lebih baik daripada jenis bibit yang kurang baik / tidak unggul. Penggunaan bibit unggul oleh para petani dapat meningkatkan produksi hasil usaha tani. Jenis bibit yang digunakan oleh para petani di daerah penelitian adalah jenis bibit Gombel Kenangan / Gombel Pelus ini memiliki banyak keunggulan dibandingkan dengan jenis bibit tembakau lainnya.

Proses pemupukan merupakan salah satu faktor yang penting untuk meningkakan hasil produksi yang lebih tinggi. Pupuk yang digunakan oleh para petani di daerah penelitian beragam, penggunaan pupuk yang diteliti dalam penelitian ini dibatasi hanya pada penggunaan pupuk organik dan pupuk kimia berupa pupuk SP36, dan pupuk ZA.

Keberadaan tenaga kerja dalam sektor pertanian khususnya pada usahatani tembakau memiliki peranan yang sangat penting. Karena dengan tanpa adanya tenaga kerja, yang dalam hal ini kita sebut petani, maka sektor pertanian tidak dapat berjalan.

Fungisida merupakan salah satu jenis obat yang tidak asing didengar dalam usaha pertanian. Obat ini sering digunakan untuk meminimalisir terjadinya kerugian usahatani yang disebabkan oleh penyakit dalam suatu tanaman, dalam penelitian ini fungisida yang digunakan oleh para petani adalah dengan merk Dursban.

\section{Pembahasan hasil Penelitian}

Hasil estimasi model dapat diketahui dari hasil analisis regresi. Analisis regresi digunakan untuk mengetahui hubungan antara variabel dependen yaitu jumlah produksi (Y) dengan variabel independen yaitu Lahan (LHN), Bibit (Bt), Pupuk Kandang (PKG), Pupuk ZA (PZA), Pupuk SP36 (PSP), Fungisida (FSD), dan Tenaga Kerja (TK). Persamaan regresi dibuat dengan model logaritma natural karena adanya perbedaan satuan dan besaran dalam variabel independen. Hasil estimasi model regresi pada penelitian ini adalah sebagai berikut:

\section{Tabel 7. Hasil Estimasi Regresi}

\begin{tabular}{lccc}
\hline \multicolumn{1}{c}{ Variabel } & Koefisien & T-Rasio & Probabilitas \\
\hline C & 0.759 & 5.154 & 0.000 \\
LN(LAHAN) & -0.179 & -2.416 & 0.018 \\
LN (BIBIT) & 0.375 & 5.028 & 0.000 \\
LN (SP36) & -0.031 & -0.716 & 0.475 \\
LN (PZA) & 0.015 & 0.311 & 0.756 \\
LN (PORGANIK) & 0.381 & 4.802 & 0.000 \\
LN (FUNGISIDA) & 0.092 & 2.77 & 0.007 \\
LN (TENAGAKERJA) & 0.004 & 0.635 & 0.526 \\
\hline Adjusted R-Squared & & & $\mathbf{0 . 8 8}$ \\
F-Statistic & & & $\mathbf{9 0 . 7 2}$ \\
Retunto Scale & Sumber: Data Primer 2017, diolah & $\mathbf{0 , 8 4}$ \\
\hline \multicolumn{4}{c}{. } \\
\end{tabular}

Dari tabel 7 di atas dapat dilihat model estimasi regresi adalah : 


\section{$\operatorname{LnY}=0,759-0,179 \operatorname{lnLAHAN}+0,375$ $\operatorname{lnBIBIT}-0,031 \operatorname{lnSP} 36+0,015 \operatorname{lnZA}+$ $0,381 \quad \operatorname{lnORGANIK}+0,092$ lnFUNGISIDA $\quad+\quad 0,004$ InTENAGAKERJA}

Hasil regresi linier terkait dengan hubungan antara variabel independen yang meliputi : luas lahan, bibit, pupuk SP36, pupuk ZA, pupuk Organik, Fungisida, Tenaga Kerja terhadap variabel dependen yaitu jumlah produksi tembakau.

\section{Deteksi Heterokedastisitas}

Pembuktian mengenai adanya asumsi homokedastisitas pada model, dapat dibuktikan melalui uji heteroskedastisitas. Uji Heteroskedastisitas bertujuan untuk mengetahui apakah didalam model terdapat ketidaksamaan varians melalui nilai residual. Salah satu cara untuk melakukan uji heteroskedastisitas adalah menggunakan metode white. Suatu model dikatakan tidak memiliki sifat heteroskedastisitas apabila nilai Obs* $\mathrm{R}$ squared prob.Chi-Square $>\alpha$ (derajat kesalahan). Namun apabila nilai Obs*R squared prob.Chi-Square $<\alpha$, maka didalam suatu model tersebut memiliki sifat heteroskedastisitas.

Tabel 8. Hasil Uji Heterokedastisitas White

\begin{tabular}{llll}
\hline F-statistic & 1.714 & Prob. F(7,78) & 0.117 \\
Obs*R-squared & 11.466 & Prob. Chi-Square(7) & 0.119 \\
Scaled explained SS & 10.285 & Prob. Chi-Square(7) & 0.173 \\
\hline \multicolumn{4}{c}{ Sumber.:Data Primer 2017, diolah }
\end{tabular}

Hasil dari uji heteroskedastisitas White disajikan pada tabel 8 melalui tabel tersebut dapat kita lihat bahwa nilai Obs*R-Squared Prob.Chi-Square menunjukkan angka 0,119. Sedangkan tingkat derajat kesalahan hasil regresi dalam penelitian ini adalah $5 \%$ atau 0,05. Sehingga dapat kita simpulkan bahwa pada model dalam penelitian ini tidak mengandung sifat heteroskedastisitas karena nilai Obs*R-Squared Prob.ChiSquare $0,119>$ nilai $\alpha$ sebesar 0,05 .

\section{Deteksi Multikolinearitas}

Untuk menentukan apakah model dalam penelitian ini mengandung sifat multikolinearitas atau tidak, peneliti melihat dari nilai Variance Inflation Factor (VIF) dari masing-masing variabel bebas. Semakin besar nilai VIF, maka kolinearitas dari variabel bebas tersebut semakin tinggi. Gujarati (2010) menerangkan bahwa sebagai aturan baku, jika nilai VIF suatu variabel melebihi 10 , yang akan terjadi dimana jika nilai $R_{j}^{2}$ melebihi 0,90, variabel tersebut dikatakan sangat kolinear.

Tabel 9. Hasil Uji Multikol - Centerted VIF

\begin{tabular}{cc}
\hline Variabel & Nilai Centered VIF \\
\hline LOG (LAHAN) & 2.566065 \\
LOG (BIBIT) & 5.732193 \\
LOG (SP36) & 3.891385 \\
LOG (PZA) & 5.299732 \\
LOG (PORGANIK) & 6.815229 \\
LOG (FUNGISIDA) & 2.675759 \\
LOG (TENAGAKERJA) & 2.867253 \\
\hline Sumber-Data Primer 2017, diolah
\end{tabular}

Nilai Variance Inflation Factor (VIF) dari masing-masing variabel bebas, seluruh variabel bebas dalam penelitian ini memiliki nilai VIF kurang dari 10 . Sehingga dapat disimpulkan bahwa model dalam penelitian ini tidak mengandung unsur multikolinearitas yang tinggi.

\section{Pengujian Uji F}

Pada dasarnya, uji-F digunakan untuk mengetahui apakah seluruh variabel independent secara bersama-sama memiliki pengaruh terhadap variabel dependent. Nilai $\mathrm{F}$ hitung atau F-Statistic beserta nilai probabilitasnya dapat dilihat melalui hasil regresi pada tabel 6 . Uji F juga dapat dilakukan dengan cara membandingkan nilai $F$-Statistic dengan nilai $F$-Table. Apabila nilai $F$-Statistic > 
nilai $F$-Table, maka variabel bebas pada model penelitian ini, berpengaruh signifikan secara simultan terhadap variabel terikat. Pada tabel 6 tersebut, dapat kita ketahui bahwa nilai probabilitas $F$-Statistic adalah 90,72, sedangkan nilai F-Tabel 2,13, sehingga dapat disimpulkan bahwa seluruh variabel bebas pada model penelitian ini secara simultan mempengaruhi variabel terikat.

\section{Koefisien Determinasi $\left(\mathbf{R}^{\mathbf{2}}\right)$}

Koefisien determinasi digunakan untuk mengukur seberapa jauh kemampuan model dalam menerangkan variasi variabel dependen. Nilai koefisien determinasi adalah nol sampai satu. Nilai yang kecil berarti kemampuan variabelvariabel independen dalam menjelaskan variasi variabel dependen sangat terbatas. Melalui tabel 6 dapat kita lihat bahwa nilai koefisien determinasi adjusted $R$-Squared sebesar 0,88 yang berarti bahwa hasil regresi dari variabel bebas $(\mathrm{X})$ dapat menjelaskan variabel terikat (Y) sebesar $88 \%$, sedangkan $12 \%$ sisanya dijelaskan oleh variabel lain.

\section{Uji Individual (Uji t)}

Uji-t digunakan untuk menilai apakah koefisien suatu variabel independen berpengaruh secara signifikan terhadap variabel dependen. Metode ini digunakan dengan cara nembandingkan nilai $t$-ratio dengan $t$-table. Apabila nilai $t$ ratio lebih besar daripada nilai t-tabel, maka dapat diambil kesimpulan bahwa variabel independen tersebut berpengaruh secara signifikan terhadap variabel dependen. Jika sebaliknya, nilai $\mathrm{t}$ ratio lebih kecil daripada nilai t-table, maka variabel independen tersebut tidak berpengaruh signifikan.

Uji $t$ dalam penelitian ini menggunakan metode one tail atau satu arah. Metode one tail digunakan untuk mengetahui seberapa besar pengaruh suatu variabel independent terhadap variabel dependent, tanpa melihat bentuk pengaruh dari masing-masing variabel independet.
Alasan menggunakan metode one tail adalah karena telah diketahui dari model fungsi produksi Cobb-Douglass bahwa seluruh faktor produksi dapat memberikan kontribusi yang positif terhadap jumlah produksi, sehingga uji-t pada penelitian ini hanya melihat besarnya pengaruh masingmasing faktor produksi terhadap jumlah produksi.

Dalam bahasa uji signifikansi, sebuah statistik dikatakan signifikan secara statistik jika nilai dari uji statistiknya berada di daerah kritis. Pada kasus ini, hipotesis nol ditolak. Sebaliknya, sebuah pengujian dikatakan tidak signifikan secara statistik, jika nilai dari uji statistiknya berada di daerah penerimaan (Gujarati, 2010). Beberapa hasil dari pengujian hipotesis berdasarkan uji-t pada penelitian ini, antara lain:

\section{Uji hipotesis variabel luas lahan}

Berdasarkan tabel 6, dapat kita ketahui bahwa t-ratio variabel luas lahan bernilai negatif sebesar 2.416 dengan nilai probabilitas sebesar 0,018. Sedangkan nilai t-tabel pada tingkat kesalahan $5 \%$ adalah 1,664. Sehingga peneliti harus menerima $\mathrm{H}_{0}$ dan menolak $\mathrm{H}_{1}$, karena nilai t-ratio < t-tabel. Pengujian hipotesis pada variabel tersebut menunjukan bahwa luas lahan tidak memiliki pengaruh secara nyata terhadap jumlah produksi, dan tidak sesuai dengan hipotesis yang diajukan.

\section{Uji hipotesis variabel bibit}

Berdasarkan Tabel 6, dapat kita ketahui bahwa t-ratio variabel bibit bernilai positif sebesar 5,028 dengan nilai probabilitas 0,0000 . Sedangkan nilai $t$ table pada tingkat kesalahan $5 \%$ sebesar 1.664. Sehingga peneliti harus menolak $H_{0}$ dan menerima $H_{l}$, karena nilai $t$-ratio $>t$ table.

\section{Uji hipotesis variabel pupuk SP36}

Berdasarkan tabel 6, dapat kita ketahui bahwa t-ratio variabel pupuk SP36 bernilai negatif sebesar 0.716 dengan nilai probabilitas sebesar 0,475. Sedangkan 
nilai t-tabel pada tingkat kesalahan $5 \%$ adalah 1,664. Sehingga peneliti harus menerima $\mathrm{H}_{0}$ dan menolak $\mathrm{H}_{1}$, karena nilai t-ratio < t-tabel. Pengujian hipotesis pada variabel tersebut menunjukan bahwa pupuk SP36 tidak memiliki pengaruh secara nyata terhadap jumlah produksi, dan tidak sesuai dengan hipotesis yang diajukan.

\section{Uji hipotesis variabel pupuk ZA}

Berdasarkan tabel 6, dapat kita ketahui bahwa t-ratio variabel pupuk ZA bernilai positif sebesar 0,311 dengan nilai probabilitas sebesar 0,756. Sedangkan nilai t-tabel pada tingkat kesalahan $5 \%$ adalah 1,664. Sehingga peneliti harus menerima $\mathrm{H}_{0}$ dan menolak $\mathrm{H}_{1}$, karena nilai t-ratio < t-tabel. Pengujian hipotesis pada variabel tersebut menunjukan bahwa pupuk ZA tidak memiliki pengaruh secara nyata terhadap jumlah produksi, dan tidak sesuai dengan hipotesis yang diajukan.

5. Uji hipotesis variabel pupuk organik

Berdasarkan tabel 6, dapat kita ketahui bahwa t-ratio variabel pupuk organik bernilai positif sebesar 4.802 dengan nilai probabilitas 0,000 . Sedangkan nilai t-tabel pada tingkat kesalahan 5\% adalah 1,664. Sehingga peneliti harus menolak $\mathrm{H}_{0}$, dan menerima $\mathrm{H}_{1}$ karena nilai $\mathrm{t}$-ratio > t-tabel. Pengujian hipotesis pada variabel tersebut menunjukan bahwa pupuk organik memiliki pengaruh secara nyata terhadap jumlah produksi, dan sesuai dengan hipotesis yang diajukan.

\section{Uji hipotesis variabel fungisida}

Berdasarkan Tabel 6, dapat kita ketahui bahwa t-ratio variabel bibit bernilai positif sebesar 5,028 dengan nilai probabilitas 0,0000 . Sedangkan nilai $t$ table pada tingkat kesalahan $5 \%$ sebesar 1.664. Sehingga peneliti harus menolak $H_{0}$ dan menerima $H_{1}$, karena nilai $t$-ratio $>t$ table. Pengujian hipotesis pada variabel tersebut menunjukan bahwa fungisida memiliki pengaruh secara nyata terhadap jumlah produksi, dan sesuai dengan hipotesis yang diajukan.

7. Uji hipotesis variabel tenaga kerja

Berdasarkan tabel 6, dapat kita ketahui bahwa t-ratio variabel tenaga kerja bernilai positif sebesar 0,635 dengan nilai probabilitas sebesar 0,526. Sedangkan nilai t-tabel pada tingkat kesalahan $5 \%$ adalah 1,664. Sehingga peneliti harus menerima $\mathrm{H}_{0}$ dan menolak $\mathrm{H}_{1}$, karena nilai $\mathrm{t}$-ratio < $\mathrm{t}$-tabel. Pengujian hipotesis pada variabel tersebut menunjukan bahwa pupuk tenaga kerja tidak memiliki pengaruh secara nyata terhadap jumlah produksi, dan tidak sesuai dengan hipotesis yang diajukan.

\section{Efisiensi Teknis}

Suatu penggunaan faktor produksi dikatakan mencapai efisiensi secara teknis apabila faktor produksi yang digunakan dapat menghasilkan produksi yang maksimum (Soekartawi, 1993). Hanafie (2010) juga menjelaskan bahwa efisiensi teknis dapat tercapai manakala petani mampu mengalokasikan faktor produksi sedemikian rupa sehingga produksi yang tinggi dapat dicapai. Berdasarkan hasil olah data melalui responden, hasil efisiensi teknis produksi usahatani tembakau di Desa Munggangsari, Kecamatan Kaliangkrik, Kabupaten Magelang, sangat beragam. Hasil pengolahan data menggunakan software DEA Version 2.1 mengenai efisiensi teknis di lokasi penelitian dapat dilihat pada Tabel 11 . Suatu Decision Making Unit (DMU) dikatakan efisien secara teknis apabila nilai efisiensi teknisnya sama dengan satu $(=1)$. 
Tabel 10. Hasil Efisiensi Teknis

\begin{tabular}{|c|c|c|c|}
\hline No & Kategori & Jumlah & Frekuensi \\
\hline 1 & $0,400-0,499$ & 1 & $1,2 \%$ \\
\hline 2 & $0,500-0,599$ & 38 & $44,2 \%$ \\
\hline 3 & $0,600-0,699$ & 30 & $34,9 \%$ \\
\hline 4 & $0,700-0,799$ & 5 & $5,8 \%$ \\
\hline 5 & $0,800-0,899$ & 2 & $2,3 \%$ \\
\hline 6 & $0,900-0,999$ & 6 & $7 \%$ \\
\hline 7 & 1,000 & 4 & $4,6 \%$ \\
\hline \multicolumn{2}{|c|}{ Total } & 86 & $100 \%$ \\
\hline \multicolumn{2}{|c|}{ Nilai Terendah } & \multicolumn{2}{|c|}{0,464} \\
\hline \multicolumn{2}{|c|}{ Nilai Tertinggi } & \multicolumn{2}{|c|}{1,000} \\
\hline \multicolumn{2}{|c|}{ Mean } & \multicolumn{2}{|c|}{0,651} \\
\hline
\end{tabular}

Hasil efisiensi teknis dapat dilihat melalui Tabel 10. Melalui tabel tersebut dapat kita lihat bahwa nilai efisiensi teknis terendah yang diperoleh adalah 0,464, sedangkan nilai efisiensi maksimalnya adalah 1,000. Ada 5 interval nilai efisiensi teknis yang memiliki frekuensi paling sedikit, yang pertama adalah pada interval $0,400-0,499$, yang kedua $0,700-0,799$, yang ketiga $0,800-0,899$, yang keempat 0,900 - 0,999 dan yang terakhir adalah interval dengan nilai efisiensi teknis maksimum yaitu 1,000. Interval dengan jumlah frekuensi paling sedikit tersebut masing-masing memiliki jumlah 1 orang atau $1,2 \%$ dari keseluruhan responden pada masing-masing interval. Sedangkan interval yang memiliki frekuensi paling banyak, berada pada interval 0,500 - 0,599 dengan jumlah 38 orang atau $44,2 \%$ dari jumlah keseluruhan responden.

Tabel 11. Rekapitulasi Responden Yang Mencapai Efisiensi Teknis

\begin{tabular}{|c|c|c|c|c|c|c|c|c|}
\hline No. Resp & Lahan & Bibit & Sp36 & $\mathrm{ZA}$ & Organik & Fsd & $\begin{array}{c}\text { Tenaga } \\
\text { Kerja }\end{array}$ & Produksi \\
\hline 1 & 2880000 & 2250000 & 288000 & 1024000 & 2400000 & 50000 & 400000 & 36000000 \\
\hline 23 & 1620000 & 600000 & 156000 & 384000 & 1250000 & 50000 & 150000 & 15000000 \\
\hline 47 & 1980000 & 750000 & 120000 & 384000 & 1150000 & 50000 & 100000 & 18000000 \\
\hline 65 & 1980000 & 750000 & 144000 & 416000 & 900000 & 60000 & 100000 & 14400000 \\
\hline Jumlah & & & & & & & & 4 \\
\hline Presentase & & & & & & & & $4,65 \%$ \\
\hline
\end{tabular}

Tabel 11 merupakan rekapitulasi alokasi input dan jumlah produksi dari petani responden yang telah mencapai efisiensi teknis yang berjumlah empat orang atau sekitar 4,65\% dari jumlah keseluruhan 86 responden. Keempat responden tersebut, masing-masing adalah petani tembakau dengan nomor responden 1 untuk luas lahan $8000 \mathrm{~m}^{2}$ yang mencapai produksi $6000 \mathrm{~kg}$ daun tembakau, petani dengan nomor responden 23 untuk luas lahan sebesar $4500 \mathrm{~m}^{2}$ dan mencapai produksi $2500 \mathrm{~kg}$ daun tembakau, petani dengan nomor responden 47 dengan luas lahan sebesar $5500 \mathrm{~m}^{2}$ yang mencapai produksi sebesar $3000 \mathrm{~kg}$ daun tembakau, dan petani dengan nomor responden 65 dengan besaran luas lahan sebesar $5500 \mathrm{~m}^{2}$ dan tingkat produksi mencapai $2400 \mathrm{~kg}$ daun tembakau.

\section{Efisiensi Harga}

Ada beberapa kemungkinan hasil yang dapat diperoleh dari efisiensi harga. Kemungkinan pertama, kondisi efisiensi harga terjadi apabila nilai efisiensi harga adalah sama dengan satu $(=1)$. Sedangkan kemungkinan kedua, apabila nilai efisiensi harga lebih dari satu $(>1)$, maka alokasi faktor produksi usahatani yang dilakukan petani belum efisien secara harga, dan disarankan agar petani menambah alokasi faktor produksinya sehingga mendapatkan keuntungan secara harga. Atau terjadi kemungkinan ketiga, yaitu alokasi faktor produksi usahatani sudah tidak efisien secara harga, hal tersebut terjadi ketika nilai efisiensi harga kurang dari satu $(<1)$, dan disarankan untuk mengurangi jumlah faktor produksi.

Tabel 12. Hasil Efisiensi Harga

\begin{tabular}{ccc}
\hline Variabel & Efisiensi Harga & Keterangan \\
\hline Lahan & 2.497 & Belum Efisien \\
Bibit & 3.446 & Belum Efisien \\
Pupuk SP36 & 242.0 & Belum Efisien \\
Pupuk ZA & 14.93 & Belum Efisien \\
Pupuk Organik & 20.25 & Belum Efisien \\
Fungisida & 94.61 & Belum Efisien \\
Tenaga Kerja & 495.6 & Belum Efisien \\
\hline Efisiensi Harga Rata-rata & $\mathbf{1 2 4 . 7 6}$ & Belum Efisien \\
\hline Sumber.:Data Primer 2017, diolah &
\end{tabular}

Hasil pada tabel 12 menjelaskan bahwa variabel luas lahan, bibit, pupuk, fungisida, dan tenaga kerja memiliki nilai efisiensi harga dengan angka yang menunjukkan lebih dari satu $(>1)$. Hal 
tersebut berarti untuk variabel luas lahan, bibit, pupuk, fungisida dan tenaga kerja, responden di lokasi penelitian belum efisien secara harga, sehingga disarankan untuk menambah alokasi penggunaan faktor produksi pada variabel tersebut agar memeroleh keuntungan secara harga.

\section{Efisiensi Ekonomi}

Efisiensi ekonomi akan terjadi ketika hasil nilainya menunjukkan sama dengan satu $(=1)$. Ketika nilai efisiensi ekonomi menunjukkan angka dengan hasil lebih dari satu $(>1)$, atau kurang dari satu $(<1)$, maka efisiensi ekonomi belum tercapai. Nilai efisiensi ekonomi dapat kita ketahui dengan cara mengalikan nilai efisiensi teknis dengan nilai efisiensi harga $(\mathrm{EE}=\mathrm{ET} \times \mathrm{EH})$.

\section{Tabel 13. Hasil Efisiensi Ekonomi}

\begin{tabular}{ccc}
\hline Efisiensi Teknis & Efisiensi Harga & Efisiensi Ekonomi \\
0.651 & 124.76 & 81.218 \\
\hline \multicolumn{3}{c}{ Sumber.:Data Primer 2017, diolah }
\end{tabular}

Tabel 13 menginformasikan mengenai nilai efisiensi teknis dan nilai efisiensi harga untuk menentukan tingkat efisiensi ekonomi di lokasi penelitian. Berdasarkan nilai efisiensi teknis sebesar 0,651 dan efisiensi harga sebesar 124,76, maka dapat kita peroleh hasil efisiensi ekonomi yaitu sebesar 81,218. Nilai efisiensi ekonomi sebesar 81,218 tersebut menunjukkan bahwa aktifitas produksi tembakau di Desa Munggangsari, Kecamatan Kaliangkrik, Kabupaten Magelang, masih belum efisien secara ekonomi.

\section{Return To Scale}

Nilai Return to scale dapat kita ketahui dengan cara menjumlahkan seluruh nilai koefisien dari masing-masing variabel independent yang signifikan dari hasil estimasi regresi. Hasil tersebut didapatkan dari hasil olah data regresi dari program Eviews 7 yang disajikan pada Tabel 6. Dari hasil penjumlahan seluruh konstanta variabel, akhirnya peneliti memperoleh nilai return to scale sebesar 0,84 .

\section{PENUTUP}

\section{Kesimpulan}

1. Variabel jumlah bibit, jumlah pupuk organik dan jumlah fungisida berpengaruh signifikan terhadap variabel produksi tembakau.

2. Nilai Return to scale yang dicapai sebesar 0,84 nilai tersebut menunjukkan bahwa usahatani tembakau di lokasi penelitian berada pada kondisi decreasing return to scale.

3. Nilai efisiensi teknik belum mencapai 1 sehingga bisa dikatakan belum efisien, dan tingkat efisiensi harganya belum mencapai 1 , hal tersebut menunjukan belum efisien secara harga. Nilai efisiensi ekonomi sebesar 81,218 tersebut menunjukan bahwa aktifitas produksi tembakau di Desa Munggangsari, Kecamatan Kaliangkrik, Kabupaten Magelang masih belum efisien secara ekonomi.

\section{Keterbatasan Penelitian}

Penulis menyadari bahwa pada penelitian ini masih mempunyai beberapa kekurangan. Oleh karena itu, pada bagian ini penulis ingin menyampaikan beberapa hal yang menjadi kekurangan atau keterbatasan penelitian yang diantaranya :

1. Nilai margin error yang dipilih peneliti pada rumus slovin dalam penentuan jumlah sampel, masih sebesar $10 \%$.

2. Teknik pengambilan sampel menggunakan accidental sampling.

3. Penggunaan alat analisis yang bersifat non-parametrik menggunakan Data Envelopment Analysis.

\section{Saran}

Diperlukan penyuluhan rutin bagi petani tembakau terhadap kemajuan budidaya tembakau sehingga petani tidak ketinggalan informasi dan dapat menggunakan faktor-faktor produksi 
secara tepat sehingga dapat mencapai tingkat produksi yang efisien. Penyesuaian penggunaan faktor produksi perlu dilakukan pada usahatani tembakau hingga mencapai standart yang sudah ditentukan oleh Dinas Pertanian Dan Pangan Kabupaten Magelang agar usahatani tembakau dapat berproduksi pada tingkat yang efisien dan sudah teruji secara agronomi.

\section{DAFTAR PUSTAKA}

Badan Pusat Statistik Provinsi Jawa Tengah. (2016). Jawa Tengah dalam Angka 2016. Semarang: Badan Pusat Statistik Provinsi jawa Tengah.

Badan Pusat Statistik Kabupaten Magelang. (2016). Kecamatan Kaliangkrik dalam Angka 2016. Mungkid: Badan Pusat Statistik Kabupaten Magelang.

Badan Pusat Statistik Kabupaten Magelang. (2016). Statistik Kecamatan Kaliangkrik dalam Angka 2016. Mungkid: Badan Pusat Statistik Kabupaten Magelang.

Boediono. (1982). Seri Sinopsis Pengantar Ilmu Ekonomi No.1 Ekonomi Mikro. Yogyakarta: BPFE Yogyakarta.

Case, dan Fair. (2007). Prinsip-Prinsip Ekonomi. Jakarta: Erlangga.

Effendi, N., dan Setiawan, M. (2014). Ekonometrika : Pendekatan Teori dan Terapan. Jakarta: Salemba Empat.

Firdauzi, S. (2013). Analisis Faktor Produksi Usahatani Padi Rojolele dan Padi IR64 (Studi kasus di Desa Candirejo, Kecamatan Ngawen, Kabupaten Klaten, Jawa Tengah). eprints.undip.ac.id/38744/1/FIRDA UZI.pdf, diakses 23 Desember 2016.
Gujarati, D.N., dan Porter, D.C. (2010). Dasar-Dasar Ekonometrika. Dialihbahasakan oleh Eudenia Mardanugraha, Sita Wardhani dan Carlos Mangunsong. Jakarta: Salemba Empat.

Hanafie, R. (2010). Pengantar Ekonomi Pertanian. Yogyakarta: Andi.

Hardanis, H. \& Adistia, N. (2013). Analisis Efisiensi Faktor-faktor Produksi Usahatani Tembakau Rakyat (Studi Kasus : Kabupaten Temanggung). http://eprints.undip.ac.id/42250/, diakses 23 Desember 2015.

Mubyarto. (1985). Pengantar Ekonomi Pertanian. Jakarta: LP3ES.

Pyndick, R. S., \& Rubinfield, D.L. (2009). Mikroekonomi. Jakarta: PT Indeks.

Risandewi, T. (2013). Analisis Efisiensi Kopi Robusta di Kabupaten Temanggung.http://www.balitbangja teng.go.id/asset/file/6d55a26cb8526 7d2c8e3e929 8074a039.pdf, diakses 23 Desember 2015.

Silaen, S., \& Widiyono. (2013). Metodologi Penelitian Sosial untuk Penulisan Skripsi dan Tesis. Jakarta: In Media.

Soekartawi. (1993). Prinsip Dasar Ekonomi Pertanian, Teori dan Aplikasi. Jakarta: Grafindo Persada.

Soekartawi. (2003). Teori Ekonomi Produksi Dengan Pokok Bahasan Analisis Fungsi Cobb-Douglass. Jakarta: PT Raja Grafindo Persada.

Soekartawi, A. S., Dillon, J.L. \& Hardaker, J.B. (2011). Ilmu Usahatani dan Penelitian untuk Pengembangan Petani Kecil. Jakarta: Penerbit Universitas Indonesia. 